Excellence in Performing Arts Research

Volume 6

2019

Bell, Book and Candle and Lesbians: A Look into LGBTQ+ Lives Through the Work of John Van Druten

Phoeby L Trask

This paper won the Award for Excellence in Undergraduate Research, 2018-19.

\title{
Citation Elements
}

Trask, Phoeby L (2019). Bell, Book and Candle and Lesbians: A Look into LGBTQ+ Lives Through the Work of John Van Druten. Excellence in Performing Arts Research Vol. 6 Retrieved from https://oaks.kent.edu/epar/vol6/iss 1/bell-book-and-candle-and-lesbians-look-lgbtq-lives-through-work-john-van-druten 


\begin{abstract}
In 1950, being a member of the LGBTQ community was difficult. There were pressures to either stay in the closet and be discrete or to conform to the world around them. Many felt that the only safe space they had was found within the theatre and plays that may or may not have hints of being about them. Bell, Book and Candle by John Van Druten is a perfect example of one of those coded plays. The main protagonist Gill, a witch in New York City, and by extension her family, can be examined and analyzed as part of the LGBTQ+ community showing the struggles that they face in mid-century America. Through the use of coding and gender stereotypes, Bell, Book and Candle shows the pressures on LGBTQ+ people to either stay closeted or conform to heterosexual and cisgender norms.
\end{abstract}

\title{
Paper
}

"Homosexuality Presents Ever-Growing Problem." This was the headline of The Austin Statesman on May 24th, 1950. Later that same year, Bell, Book and Candle was published and produced on November 14th at the Ethel Barrymore Theatre in New York City. At the time, being a member of the LGBTQ community was difficult and often times LGBTQ+ people kept their identity a secret.

Bell, Book and Candle revolves around a woman named Gillian Holroyd, but she is not a normal woman. She is a witch living in Greenwich Village in 1950. She is the landlady of what we can assume is a boarding house or some type of apartment complex. Her Aunt Queenie, also called Miss Holroyd, and her brother Nicky are also a witch and warlock respectively. They must live this lifestyle secretly in hopes they will not be persecuted like they were before in America. Gill is in a rut and believes that she needs a new man to fill the void. She refuses to fall in love, though, and Queenie reminds her of an old wives' tale stating that if a witch or warlock falls in love, they will lose their powers. One day, when Gill returns from Mexico, she meets the new tenant Shepard Henderson. He comes to Gill to complain about Queenie in his apartment when he is not there or without his permission. Gill learns that Shep is engaged to her old enemy from college, Merle Kittredge.

Gill puts a spell on Shep to make him fall in love with her. To make him happier, she summons an author he would like to meet named Redlitch. Redlitch writes about witches and Shep would like to be his publisher. He tells Shep the signs of identifying a witch, but Gill ends up renouncing her magic anyway. Nicky works with Redlitch to write a book about witches in New York, effectively outing himself and his family as witches. When Gill tells Shep that she put a spell on him, Shep has another witch remove the spell and leaves Gill. When he returns to get some things from his apartment, he realizes that Gill has truly fallen in love with him and has lost her powers. Even after the spell is gone he still loves her. Now that she is not a witch anymore, they can be together.

Feminism and gender norms play a big part in the plot of this play. Katherine Young says in her book Sanctifying Misandry: Goddess Ideology and the Fall of Man that "witchcraft is cutting edge feminism" (136) and that the "current coven [shown on stage or in television] is modernization of the witch. They're fun to watch, but they also deal with issues of abuse and love" (136). Van Druten's play is an excellent example of Young's observations. He shows that these witches represent a kind of feminism because most do not marry or even worry about men. They treat each other like they were equal to men, and sometimes even more powerful because 
they might have stronger powers than men. He also demonstrates that women and LGBTQ+ people in the 1950s struggled with this because they felt the pressure to conform.

Most of the women in this play are portrayed as multidimensional people, but Gill is flawed as a feminist example. She wants a man, but does not need one and is a very powerful witch. Then Shep enters her life and she must decide how long it would take to get him to fall in love with her. Finally, the straw that breaks the camel's back is the fact that Shep is engaged to Merle Kittredge, Gill's former enemy. She decides to "steal" him away from her and Queenie even tells Shep that "[Gill] wouldn't have used magic if she'd had the time for the usual feminine methods. No matter how great of enemies she and Miss Kittredge were" (Van Druten 115 ) and that Merle was the reason "She went after [Shep]..." (114). Finally, it is a strong message that Gill changes to be with Shep. It is against her choice, but she just can't help that she is in love with Shep and she loses her powers. This shows the ideas of the time when women were supposed to be willing to change to suit their husbands because their husbands were the ones who supported them and took care of them.

Coding is a term used in theatre to describe a play that can mean something else to two different types of audiences. In LGBTQ theatre, it occurs when an audience full of heterosexual cisgendered people see a play about a witch and a man falling in love, but an LGBTQ+ audience will see that being a witch or warlock is an allegory for being a member of the community. William M. Hoffman refers to Bell, Book and Candle "as one of the 'hidden gay plays' that 'gay theatergoers interpreted" (Sinfield 211). The lives of the characters in Bell, Book and Candle exhibit this in basic 1:1 ratios including the image of "witches," the lifestyle of the characters including the Zodiac Bar, the shame placed on members of the community, and the closet these characters are forced to live in.

In this play, there are some basic correlations between the LGBTQ+ community and the way witches live, starting with the fact that they are a coven of witches and "could well be a queer clique" (Sinfield 211). Another correlation is the Kinsey Scale referenced on page 10 of this play. The Kinsey Scale is a one-to-ten scale created by Alfred Kinsey, published in 1948, where an individual is placed on the spectrum of heterosexual to homosexual. Shep wishes that he had published Redlitch's book about witches because "it sold like the Kinsey Report" (10). While a straight audience member might see this as simple as the Kinsey Report sold well, an LGBTQ+ audience member might start to pay attention. Van Druten is signaling to audience members who might be in the know that there is more going on than there appears to be.

There are other innuendos that appear throughout the play. Near the beginning of the play, Shep asks if Aunt Queenie is in dramatics because he can hear her chanting in her apartment. Gill responds with "Well, it is a kind of dramatics" (Van Druten 7). This can be seen as just a joke about witchcraft and the dramatic side of Aunt Queenie but again, this might alert the audience. LGBTQ+ people are often accused of using their orientation as a way to be dramatic and call attention to themselves instead of just being true to themselves. Another innuendo occurs later in the play when Nicky and Gill are arguing about the book that Nicky wants to publish with Redlitch. He told Redlitch that he is a warlock and that "[Gill had an] idea the things I've shown him and told him" (Van Druten 91). One can see this as either Nicky teaching Redlitch about what witches and warlocks do, or as Nicky teaching Redlitch about LGBTQ+ culture: where they go, who they spend time with, and other activities that Redlitch would not otherwise know if he was not part of the community.

Within the play's coding, the image of witches and warlocks and how the ordinary human sees them is examined. One of the most obvious examples is when Shep talks about Aunt 
Queenie. He says she is "not only eccentric, but immoral, too" (Van Druten 85). This is often how LGBTQ+ people are seen. The idea shown is that there is something offensive about these people to the "normal" heterosexual people and that they are somehow monsters. Earlier in the play when Shep and Redlitch talk about witches and warlocks, with Gill and Nicky seeing the irony, Shep asks what witches look like. Redlitch responds by saying "like anyone else. Like you - or you - or you" (Van Druten 59) while pointing to them all in turn without knowing that two of them are witches. Anyone of any sexual orientation or gender looks like a human. They look just like humans even though they are treated as less and prosecuted like a monster. Redlitch continues by saying he can tell who is a witch and who is not. It is common for straight people to think that they have 'gaydar,' or the ability to identify LGBTQ+ people, but a person's inner emotional experience is unfathomable. This is comical because Shep cannot tell that Gill is a witch and she is sitting right in front of him.

The play also shows the way in which witches go unseen by "regular" people, or if they are seen, they are perceived as monsters. Queenie has a speech about sitting on the subway. She says:

[Shep would] never suspect, darling. Not in a million years. No matter what I did. Honestly, it's amazing the way people don't. Why, they don't believe there are such things. I sit in the subway sometimes, or on busses, and look at the people next to me, and I think: What would you say if I told you I was a witch? And I know they'd never believe it. They just wouldn't believe it. And I giggle and giggle to myself. (Van Druten 15)

Since LGBTQ+ people are coded as witches, Van Druten is commenting that LGBTQ+ people are physically no different than anyone else, and most people did not think they really existed during the time the play was written. They are seen as some sort of monster.

Witches, coded as LGBTQ+ people, are accused of "engaging in un-American activities" (98), being a type of "influenza" (62), and being "cold blooded" (72). These are often things that LGBTQ+ people hear. They are considered un-American because they are partaking in sex that is outside of traditional marriage, or perceived as a malady on society or that they are sick and need to be helped, or because they are seemingly cold blooded and less than human.

The witches face pressure to conform based on the assumption that they have chosen their lifestyle when in reality they are born witches and could be nothing else, keeping with the essentialist view of sexuality. When Shep proposes marriage, Gill is hesitant. She does not want to leave the life she has now and, even though she is trying to renounce magic, she is afraid that she is falling in love with Shep. She says, "I don't think I'm cut out for marriage, that's all" (78). When Shep presses her further by asking what she means, she finally says, "the way I've lived" (79). She is afraid that her lifestyle has caused her to never be cut out for marriage. This can be interpreted this two ways. First, same sex marriages were not allowed during this era. She could be implying that she is not cut out for marriage as a code, saying that witches cannot marry as LGBTQ+ people cannot marry. Later in the conversation, she says things like "It's habitforming!" (108) and "I've lived among it. And I know what it can do to you" (108) which goes back to her lifestyle. Shep would not understand the temptation of using magic because he has never been a part of it. We can also take this to mean that straight people could never understand the queer emotional experience. 
Another example of this is when Queenie says "how impossible, really - love is. Not sex. Sex is allowed. In fact, it's almost encouraged!" (115). This shows again that this "lifestyle" that LGBTQ+ people seem to conform to is assumed to is based on sex without the capacity for love.

Finally, Gill feels pressured to change for Shep. She tries to renounce magic altogether and makes it impossible for Nicky to publish the book that would likely out them as witches. At the end of the play, she realizes that she has truly fallen in love with Shep so she has lost her powers, and she now has the ability to cry. This can be seen as another instance of coding. The character that is unordinary finds an ordinary boy and falls in love with him. He saves her and takes her away from the negative, cold-blooded lifestyle she has been leading. She literally becomes more human. She loses the ability to influence others with magic, but can now blush and cry. This is a common narrative in LGBTQ+ lives where individuals are encouraged to change with the promise that once they do, they will be saved.

Gill, Nicky, and Aunt Queenie frequent a bar that is known to be the hotspot for witches and warlocks. This is the Zodiac bar and can be taken for an LGBTQ+ hangout spot. Redlitch tells Shep, "They have their regular hangouts - cafes, bars, restaurants. Ever hear of a nightclub called the Zodiac?" (57). There is a common theme within LGBTQ+ communities where they find somewhere that is either owned by someone in the community or an ally, and they make it a meeting place where they are not judged, and can be themselves without fear of persecution. When Gill mentions the Zodiac Club, Shep says that he had never heard of the place and Gill responds by saying, "I don't imagine you would" (12). She puts out a hint to see if Shep could pick up on it. If this is a place that people like her frequent, he could either say that it is his favorite place and Gill would believe he is like her, or he could say he hates it and she would realize that he knows about people like her but does not like it. By his reaction, Gill knows that he is not like her and that he does not really know anything about people like her. He even tells Redlitch later that he "[doesn't] think [he] thought of their meeting at all" (59). This is another example that straight people wouldn't know anything about LGBTQ+ people meeting. Redlitch, though, is a character that knows about witches and is trying to find more information about them. He knows about the Zodiac and tells Shep, Gill, and Nicky about the club, but Nicky and Gill feign ignorance of the club.

Van Druten also codes the pressures on LGBTQ+ people in the shame that Gill feels towards herself, her powers, and her family. Queenie states her fears when she tells Gill, "sometimes I think you're ashamed of being what you are" (17). Gill tells Queenie that she is not, but her behavior displays otherwise. She asks Queenie, "Do you ever wish you weren't?" (18), but Queenie could never see herself as anything else. Gill wants to be relieved of what she knows, or "unenlightened" (18). When Gill finds out that Shep has gone to Mrs. de Pass to have the spell removed, she becomes disgusted. She says things like "Oh, it's revolting! [Shep] getting mixed up with it. Going to see [Mrs. de Pass]. He's too good for that sort of thing" (131), and "It's cheapening to him. Scrabbling about in the gutters of the supernatural with Mrs. de Pass" (131). Gill's reactions show that she is becoming disgusted with what she is and the people who are most like her. Gill is changing to fit into the heterosexual cisgendered stereotype and is now finding the LGBTQ+ lifestyle disgusting because of the way people outside of the community are expected to feel. She is becoming more "ordinary" as she changes. Finally, when she and Shep are fighting, she tells him that he "might go to the local minister and get me exorcised with bell, book, and candle" (135). She has finally come to the point where she is ashamed and is telling him that he should change her if he is unhappy with the way she is. This can also be a 
reference to the general intolerance that a large population has with LGBTQ+ people, especially at the time.

The last thing that is coded into this play is the idea of the closet for LGBTQ+ people. There is a difference in Bell, Book and Candle between Gill, who believes that witches should practice their magic in private or not at all, and Mrs. de Pass who is an out and proud witch. She openly talks about witches and tells Redlitch all about her practice. Gill feels pressured to remain in the closet and to not let Queenie or Nicky interfere with other's lives. She wants to make sure that the magic is "discreet" (16) and makes Queenie promise that she will not practice magic in the apartment building because it increases the chance that they will be caught. This is a common experience for LGBTQ+ people; they are afraid of being outed because they were seen with the wrong people or doing the wrong things. When Shep goes to Mrs. de Pass to have the spell on him reversed, Gill says, "It's people like [Mrs. de Pass] who make me wish we had the Inquisition back again" (134). People who are out and flamboyant can make closeted people nervous, either because they are afraid that they will be exposed by association or because openness may make straight people reactionary.

Bell, Book and Candle by John Van Druten was written when LGBTQ+ people were suffering and looking for hope. Using the allegory of witches, Van Druten showed the American public just what it meant to be an underrepresented and oppressed minority even if they did not understand it was about something they were actively fighting. I like to think that Van Druten might have done this out of spite, or as an inside joke. Gill, though, betrays us and changes for the man she loves, giving into the norms and effectively breaking her ties with her brother and aunt. Van Druten used gender norms through feminist theory and coding to show the pressures put on LGBTQ+ people to conform and change as Gill did in this work. 


\section{Works Cited}

Marlow, James. "Homosexuality Presents Ever-Growing Problem.” The Austin Statesman, May 24, 1950 p. 1.

Sinfield, Alan. Out on Stage: Lesbian and Gay Theatre in the Twentieth Century. Yale University Press, 1999.

Van Druten, John. Bell, Book and Candle. Random House, 1951.

Young, Katherine K. Sanctifying Misandry: Goddess Ideology and the Fall of Man. McGill-Queen's University Press, 2010. 